\title{
Application of Decision-Making Expert Systems in Transportation
}

\section{Primjena ekspertnih sustava odlučivanja u prijevozu}

\author{
Yusif Gasimov \\ Azerbaijan University, Baku \\ Institute of Mathematics and Mechanics \\ Institute for Physical Problems, Baku State \\ University, Azerbaijan \\ e-mail: yusif.gasimov@au.edu.az
}

\author{
Latifa Agamalieva \\ Azerbaijan University, Baku \\ Institute for Physical Problems, Baku \\ State University, Azerbaijan \\ e-mail: latifa.aghamaliyeva@au.edu.az
}

\author{
Asif Pashayev \\ Azerbaijan University, Baku \\ Institute of Mathematics and \\ Mechanics, Baku, Azerbaijan \\ e-mail: asif.pashayev@au.edu.az \\ Bakhram Azizov \\ Azerbaijan University, Baku, \\ Azerbaijan \\ e-mail:bahram.azizov@au.edu.az
}

\section{Summary}

This paper discusses the problem of risk estimate and choice of the rational variants in the transportation using expert information systems. The pairwise comparison method (Saaty's method) is used to determine the weights of chosen criteria. An example is given that compares logistic risks in shipping, railway and aviation transport. The input data are taken in the example are formal and can be chosen for the concrete problems. This example is solved by both non-fuzzy and fuzzy approach. It is shown that with the set of data in the railway transport is the optimal option. The results demonstrate the efficiency of the proposed method.

\section{Sažetak}

$U$ radu se analizira problem procjene rizika i odabira racionalnih opcija u prijevozu uporabom ekspertnih informacijskih sustava. Metoda usporedbe po parovima (Saaty metoda) upotrijebljena je kako bi se utvrdilo značenje odabranih kriterija. Donosi se primjer u kojemu se uspoređuju logistički rizici u pomorskom, željezničkom i zračnom prijevozu. Uneseni podaci koji se koriste u primjeru općeniti su i mogu se odabrati za konkretne primjere. Odabrani primjer riješen je s pomoću dviju logika: jasne i nejasne. Pokazalo se da su podaci u željezničkom prijevozu optimalno rješenje. Rezultati pokazuju učinkovitost predložene metode.

\section{INTRODUCTION / Uvod}

The effectiveness of logistics activities in the supply chains and their individual participants, expressed by key indicators, is influenced by the so-called general risks (for example: natural, political, market) and specific logistics risks. For a supply chain of specific goods or a participant, its own risk system corresponds, which is formed depending on the logistic functions performed (transportation, warehousing, procurement management, etc.), industry sector, scale of activity (local, regional, national, international, global), applied technologies, selected development strategies and a number of other factors (Pleteneva, 2014; Tzeng \& Huang, 2011; Ruiz et al., 2012; Yeh et al., 1886).

In logistics systems and supply chains, risks of a logistic and non-logistic nature are manifested. Logistical risks are the risks of performing logistics operations in transportation, warehousing, cargo handling, inventory management and risks of logistics management, which arise at different levels of decomposition of the logistics system (Suruchi Chawla, 2018).

Non logistical risks are risks external to the enterprise's logistics caused by natural, environmental, political, market, social causes and risks characteristic of any area of management associated with damage to fixed assets of administrative and management purposes, accidents, dismissal and the death of the staff, etc. (Pashayev, 2005; Yeh et al., 1886; Uhrmacher \& Weyns, 2009).

The functional cycle of each operating logistics system is dependent on a wide range of causes or factors characterizing various types of uncertainty. The uncertainty of the conditions for the implementation of logistics activities, on the one hand, implies a risk, and on the other hand, it opens up opportunities for further development.

Formalization and creation of models for the development of logistics systems are characterized by multi-criteria, the presence of several possible areas of improvement, internal 
complexity due to the need to process a large amount of qualitative information that characterizes the micro and macroenvironment required for logistics management and poorly quantifiable. In other words, logistic management is carried out under conditions of a high degree of uncertainty, which can be explained by a lack of information, its incompleteness or internal inconsistency and ambiguity of the initial data (Velasquez \& Hester, 2013, Wojciech Sałabun, 2014).

The use of the theory of fuzzy sets (TFS) on the basis of the concept of the membership function is one of the ways to solve this kind of tasks, decision-making problems under uncertainty. Theoretical aspects of the construction of mathematical models based on fuzzy logic received wide coverage by various scientists (Skorospelov, 2005; Orlovsky, 1981; Azizov et al. 2015; Hamidov et al., 2018; Vlkovský et al., 2017).

One of the advantages of TFS is the ability to use fuzzy sets when modelling multicriteria problems, in which there is no clear information, i.e. fuzzy modelling allows us to more adequately describe objects with uncertainty, take into account multicriteriality, and make a choice from a variety of alternatives according to the criteria defined on different types of measurement scales (Andreichikov \& Andreichikova, 2000).

Decision Support Systems (DSS) based on TFS are not focused on automating the functions of the decision maker, but on providing him assistance in finding a good solution. Of course, the mathematical and software solution support systems include formalized procedures that a decision maker can use to any degree he needs.

Another multicriteria decision-making method is Saaty's analytical hierarchical process (AHP) in which we choose the best option out of a finite set of options with respect to the criteria we consider. When compiling the set of criteria it is important that the criteria do not depend on each other and do fully describe a given aim. The number of criteria should not be unnecessarily large. The significance of the criteria relative to the overall objective is determined by normalized weights. To determine the weights it is necessary to compile the Saaty's pairwise comparison matrix at first. Saaty's analytical hierarchical process (AHP) is used in order to solve a wide variety of decisionmaking problems (Saaty, 1980).

In this paper we strive to determine the most appropriate transportation option using this method and Saaty's AHP fuzzy extension. The fuzzification of this method is appropriate as it takes into account the uncertainty associated with decisionmaking process. We consider the application of decision-making methods based on TFS in the field of logistics management, allowing to increase the validity of management decisions and ensure the rationality of choice from the point of view of the decision maker of the most preferable risk event from the set of admissible ones.

\section{THEORY / Teorija}

\subsection{Non-fuzzy approach / Jasna logika}

Consider an example of multicriterial evaluation of options. Let's have $m$ options $a_{j}, j=1, \ldots, m$. We evaluate these options according to $n$ criteria $C_{i}, i=1, \ldots, n$ by pair comparison. For each criterion we get a square matrix

$$
A\left(C_{i}\right)=\left(a_{k j}\right), k=1,2, \ldots m, j=1,2, \ldots m,
$$

where the element $a_{k j}$ expresses the preference of the option $a_{k}$ against the option $a_{j}$.
Scale of relative importance can be seen in table 1.

Table 1 Scale of relative importance (Source: Saaty, 1980) Tablica 1. Skala relativnog značaja (Izvor: Saaty, 1980)

\begin{tabular}{|c|c|}
\hline $\begin{array}{c}\text { Intensity } \\
\text { of importance }\end{array}$ & Definition \\
\hline $\mathbf{1}$ & Equal importance \\
\hline 2 & Weak \\
\hline $\mathbf{3}$ & Moderate importance \\
\hline 4 & Moderate plus \\
\hline $\mathbf{5}$ & Strong importance \\
\hline 6 & Strong plus \\
\hline 7 & $\begin{array}{c}\text { Very strong or } \\
\text { demonstrated importance }\end{array}$ \\
\hline 8 & Very, very strong \\
\hline $\mathbf{9}$ & Extreme importance \\
\hline
\end{tabular}

Each of matrixes (2.1) has following properties: diagonal elements are equal 1, i.e. $a_{i j}=1, j=1, \ldots, m$; it is inversely symmetric; i.e., the elements symmetric with respect to the main diagonal are related as follows:

$a_{j k}=\frac{1}{a_{k j}} ;$

it is transitive; i.e. $a_{k j}=a_{k o} a_{o j}$.

These properties allow obtaining of the $m-1$ elements (not diagonal elements) of matrix to calculate other elements of square matrix of order $m$.

\section{Criterion vectors}

For each criterion $C_{i}$ we define a vector $\vec{C}_{i}, i=1, \ldots, n$.

$$
\vec{C}_{i}=\left(c_{i j}\right), \text { where } c_{i j}=\frac{1}{\sum_{k=1}^{m} a_{k j}}, j=1, \ldots, m .
$$

The vector $\vec{C}_{i}, i=1, \ldots, n$ represents vector of preferences of individual options, according to the criterion $C_{i}$.

In addition, vectors $h_{j}, j=1, \ldots, m$, are created. We introduce the vector $h_{1}$ using the first components of the vectors $\vec{C}_{i}, i=1, \ldots, n$, the vector $h_{2}$ is created using the second components, etc.

The vector $h_{j}, j=1, \ldots, m$, represents the preferences of option $a_{j}$ according to individual criteria (Rotshtein \& Shtovba, 2001).

\section{Weights of criteria}

Let's consider pair comparison of the importance of the criteria. Pair comparison of criterions is given by the square matrix

$$
V=\left(a_{k i}\right), k=1, \ldots n, i=1, \ldots n .
$$

Weights of the criterions are obtained from the formula

$$
v_{i}=\frac{1}{\sum_{k=1}^{n} a_{k i}}, i=1, \ldots, n .
$$

For each option $a_{j}, j=1, \ldots, m$, we calculate the weighted average according to the formula

$$
h\left(a_{j}\right)=\sum_{i=1}^{n} v_{i} h_{i j}
$$

The order of options is determined by the value of $h\left(a_{j}\right)$. The greater the value, the better the option (Rotshtein \& Shtovba, 2001). 


\subsection{Fuzzy approach / Nejasna logika}

In this part we extend the theory of the Section 2.1 through fuzzy approach. We replace all values from pair comparisons by fuzzy numbers. These are the elements of matrices (2.1) and the matrix (2.3). Instead of one number, we consider a fuzzy number, i.e., a triple of values. Counting with fuzzy numbers has its own rules and is somewhat more complicated than the formulas used in the Section 2.1.

Using fuzzy matrix of pair comparison of criteria, we obtain fuzzy weights $\widetilde{v}_{i}, i=1,2, \ldots n$, of the criteria $C_{i}, i=1,2, \ldots n$, in relation to the overall goal. The calculation is based on the line geometric averages $\widetilde{m}_{i}$ (Pan \& Yuan, 1997).

$m_{i 1}=\left(\prod_{j=1}^{n} \widetilde{w}_{i j 1}\right)^{\frac{1}{n}}, m_{i 2}=\left(\prod_{j=1}^{n} \widetilde{w}_{i j 2}\right)^{\frac{1}{n}}, m_{i 3}=\left(\prod_{j=1}^{n} \widetilde{w}_{i j 3}\right)^{\frac{1}{n}}$, for $i=1,2, \ldots n$,

where $\widetilde{w}_{i, j}=\left(w_{i j 1}, w_{i j 2}, w_{i j 3}\right), \widetilde{m}_{i}=\left(m_{i 1}, m_{i 2}, m_{i 3}\right)$,

$v_{i 1}=\frac{m_{i 1}}{m_{i 1}+\sum_{j=1, j \neq i}^{n} m_{j 3}}, v_{i 2}=\frac{m_{i 2}}{m_{i 2}+\sum_{j=1, j \neq i}^{n} m_{j 2}}, v_{i 3}=\frac{m_{i 3}}{m_{i 3}+\sum_{j=1, j \neq i}^{n} m_{j 1}}$, for $i=1,2, \ldots n$,

$\widetilde{v}_{i}=\left(v_{i 1}, v_{i 2}, v_{i 3}\right), i=1, \ldots, n$.

We consider $m$ options and evaluate them according to $n$ criteria. The fuzzy weights of the criteria with respect to the overall target are denoted by $\widetilde{v}_{i}, i=1, \ldots, n$.

Using the matrices $\widetilde{A}\left(C_{i}\right), i=1, \ldots, n$, and formula (2.6), we obtain fuzzy evaluations of options with respect to each criteria.

The partial fuzzy evaluation of the option $a_{j}$ with respect to the criterion $C_{i}$ is denoted by $\widetilde{h}_{j}^{i}, j=1, \ldots, m, i=1, \ldots, n$.

The overall fuzzy evaluation of the option $a_{j}$ with respect to the overall goal (taking into account all the criteria) is denoted by $\tilde{h}_{j}$. Three significant values of $\widetilde{h}_{j}=\left(h_{j 1}, h_{j 2}, h_{j 3}\right)$ are obtained as it follows:

For the calculation of the first significant value $h_{j 1}$, we consider a permutation $\{(j)\}_{i=1}^{n}$ such that $h_{j 1}^{(1)} \leq h_{j 1}^{(2)} \leq \ldots \leq h_{j 1}^{(n)}$.

Then for $k \in\{1,2, \ldots n\}$ we denote $v_{(k)}:=1-\sum_{i=1}^{k-1} v_{(i) 3}-\sum_{i=k+1}^{n} v_{(i) 1}$. Then

Let $k^{*} \in\{1,2, \ldots n\}$ be such that that it applies $v_{\left(k^{*}\right)} \leq v_{\left(k^{*}\right)} \leq v_{\left(k^{*}\right)_{3}}$.

$$
h_{j 1}=\sum_{j=1}^{k^{*}-1} v_{(i) 3} h_{j 1}^{(i)}+v_{\left(k^{*}\right)} h_{j 1}^{\left(k^{*}\right)}+\sum_{i=k^{*}+1}^{n} v_{(i) 1} h_{j 1}^{(i)} .
$$

For the calculation of the third significant value $h_{j 3}$, we consider a permutation $\{(j)\}_{i=1}^{n}$ such that $h_{j 3}^{(1)} \geq h_{j 3}^{(2)} \geq \ldots \geq h_{j 3}^{(n)}$. Then for $l \in\{1,2, \ldots n\}$ we denote

$$
v_{(l)}:=1-\sum_{i=1}^{l-1} v_{(i) 3}-\sum_{i=l+1}^{n} v_{(i) 1} .
$$

Let $l^{*} \in\{1,2, \ldots n\}$ be such that that it applies $v_{\left(l^{*}\right) 1} \leq v_{\left(l^{*}\right)} \leq v_{\left(l^{*}\right)}$. Then

$$
h_{i 3}=\sum_{i=1}^{l^{*}-1} v_{(i) 3} h_{j 3}^{(i)}+v_{\left(l^{*}\right)} h_{j 3}^{\left(l^{*}\right)}+\sum_{i=l^{*}+1}^{n} v_{(i) 1} h_{j 3}^{(i)} .
$$

The second significant value $h_{i 2}$ will be calculated according to the formula

$$
h_{j 2}=\sum_{j=1}^{n} v_{i 2} h_{j 2}^{i} .
$$

It is necessary to compare all the options with each other. Comparison of fuzzy numbers is done using the centre of gravity. If we consider the triangular fuzzy number represented by a triple of its significant values $R=\left(r_{1}, r_{2}, r_{3}\right)$, the centre of gravity $t_{R}$ of this fuzzy number $R$ is

$$
t_{R}=\frac{1}{3} \frac{r_{3}^{2}-r_{1}^{2}+r_{2} r_{3}-r_{1} r_{2}}{r_{3}-r_{1}}
$$

(Talašová, 2003).

\section{Example / Primjer}

\subsection{Example solved by non-fuzzy approach / Primjer}

\section{riješen pristupom jasne logike}

Let's assume three types of transport, i.e., three options $a_{1}, a_{2}, a_{3}$ (thus $m=3$ )

\section{$a_{1}$ - shipping transport \\ $a_{2}$ - railway transport, \\ $a_{3}$ - aviation transport.}

For consideration of three options, we assume four criteria $C_{1}, \ldots, C_{4}$ (thus $n=4$ )

$C_{1}$-price of transport,

$\mathrm{C}_{2}$-duration of transport,

$C_{3}$-time necessary to book (arrange for) the transport,

$\mathrm{C}_{4}$ - ecologic burden of transport.

Pair comparison of options according to each of criteria:

$C_{1}$

$a_{2}$ is moderately more important than $a_{1^{\prime}}$

$a_{2}$ is very, very strongly more important than $a_{3}$.

$\mathrm{C}_{2}$

$a_{3}$ is extremely more important than $a_{2}$

$a_{1}$ is weakly more important than $a_{2}$.

$C_{3}$

$a_{1}$ is strongly more important than $a_{2}$

$a_{1}$ is very strongly more important than $a_{3}$.

$\mathrm{C}_{4}$

$a_{2}$ is strongly more important than $a_{1}$

$a_{2}$ is extremely more important than $a_{3}$.

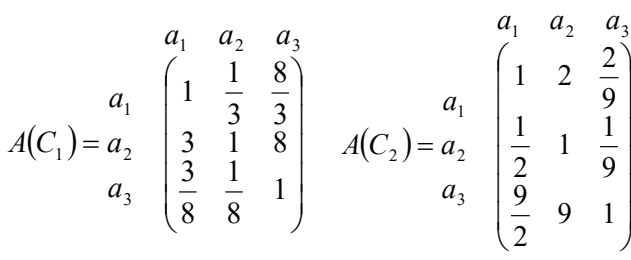

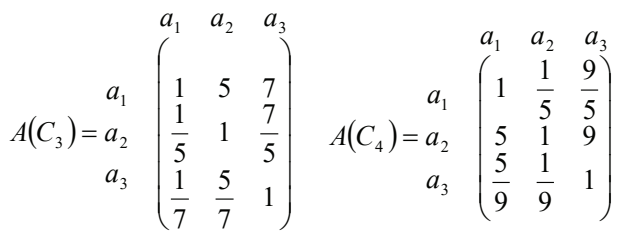

\section{Criterion vectors}

Criterion vectors are calculated according to the formula (2.2)

$$
C_{1}=(0,2286 ; 0,6857 ; 0,0857) \text {, }
$$$$
\vec{C}_{2}=(0,1667 ; 0,0833 ; 0,7500)
$$

$\vec{C}_{3}=(0,7447 ; 0,1489 ; 0,1064)$,

$\vec{C}_{4}=(0,1525 ; 0,7627 ; 0,0847)$.

Further,

$h_{1}=(0,2286 ; 0,1667 ; 0,7447 ; 0,1525)$,

$h_{2}=(0,6857 ; 0,0833 ; 0,1489 ; 0,7627)$,

$h_{3}=(0,0857 ; 0,7500 ; 0,1064 ; 0,0847)$. 
Determination of weights of criteria

Pair comparison of criteria is given by matrix

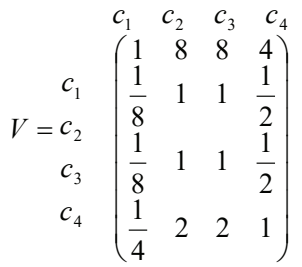

Weights of the criteria are obtained using the formula (2.4)

$$
\vec{v}=\left(\frac{2}{3} ; \frac{1}{12} ; \frac{1}{12} ; \frac{1}{6}\right) \text {. }
$$

Weighted averages of evaluations of options are determined using the formula (2.5)

$H=(0,2537 ; 0,6037 ; 0,1426)$.

As we can see, that the best option is railway transport $\left(a_{2}\right)$. The shipping transport $\left(a_{1}\right)$ is the second best option, and aviation transport $\left(a_{3}\right)$ is the third one.

\subsection{Example solved by fuzzy approach / Primjer riješen pristupom nejasne logike}

Fuzzy matrix of pair comparison of criteria is as follows:

$$
\widetilde{W}=\left(\widetilde{w}_{j}\right)=\begin{gathered}
\widetilde{c}_{1} \\
\widetilde{c}_{2} \\
\widetilde{c}_{3} \\
\widetilde{c}_{4}
\end{gathered}\left(\begin{array}{cccc}
(1,1,1) & (7,8,9) & (7,8,9) & (3,4,5) \\
\left(\frac{1}{9}, \frac{1}{8}, \frac{1}{7}\right) & (1,1,1) & \left(\frac{1}{2}, 1,2\right) & \left(\frac{1}{3}, \frac{1}{2}, 1\right) \\
\left(\frac{1}{9}, \frac{1}{8}, \frac{1}{7}\right) & \left(\frac{1}{2}, 1,2\right) & (1,1,1) & \left(\frac{1}{3}, \frac{1}{2}, 1\right) \\
\left(\frac{1}{5}, \frac{1}{4}, \frac{1}{3}\right) & (1,2,3) & (1,2,3) & (1,1,1)
\end{array}\right)
$$

(Reader can compare this matrix to the matrix (3.2) in non-fuzzy approach.)

By substituting into formulas (2.6) we obtain:

$\widetilde{m}_{1}=(3,4820 ; 4,0000 ; 4,4860), \widetilde{m}_{2}=(0,3689 ; 0,5000 ; 0,7311)$,

$\widetilde{m}_{3}=(0,3689 ; 0,5000 ; 0,7311), \widetilde{m}_{4}=(0,6687 ; 1,0000 ; 1,3161) ;$

$\widetilde{v}_{1}=(0,5562 ; 0,6667 ; 0,7613), \widetilde{v}_{2}=(0,0534 ; 0,0833 ; 0,1392)$,

$\widetilde{v}_{3}=(0,0534 ; 0,0833 ; 0,1392), \widetilde{v}_{4}=(0,1011 ; 0,1667 ; 0,2377)$.

These resulting fuzzy weights are normalized.

We can see that the first criterion is very important with respect to the other criteria.

It is necessary to determine the fuzzy preferences among options due to the individual criteria.

The fuzzy matrices of these pair comparisons are as follows:

$$
\begin{aligned}
& \widetilde{A}\left(C_{1}\right)=\begin{array}{l}
a_{1} \\
a_{2} \\
a_{3}
\end{array}\left(\begin{array}{ccc}
a_{1} & a_{2} & a_{3} \\
(1,1,1) & \left(\frac{1}{4}, \frac{1}{3}, \frac{1}{2}\right) & \left(\frac{5}{3}, \frac{8}{3}, \frac{1}{3}\right) \\
(2,3,4) & (1,1,1) & (7,8,9) \\
\left(\frac{3}{1}, \frac{3}{8}, \frac{3}{5}\right) & \left(\frac{1}{9}, \frac{1}{8}, \frac{1}{7}\right) & (1,1,1)
\end{array}\right) \\
& \tilde{A}\left(C_{2}\right)=\begin{array}{ccc}
a_{1} & a_{2} & a_{3} \\
a_{2} \\
a_{3}
\end{array}\left(\begin{array}{ccc}
(1,1,1) & (1,2,3) & \left(\frac{2}{1}, \frac{2}{9}, \frac{2}{7}\right) \\
\left(\frac{1}{3}, \frac{1}{2}, 1\right) & (1,1,1) & \left(\frac{1}{9}, \frac{1}{9}, \frac{1}{8}\right) \\
\left(\frac{7}{2}, \frac{9}{2}, \frac{1}{2}\right) & (8,9,9) & (1,1,1)
\end{array}\right)
\end{aligned}
$$

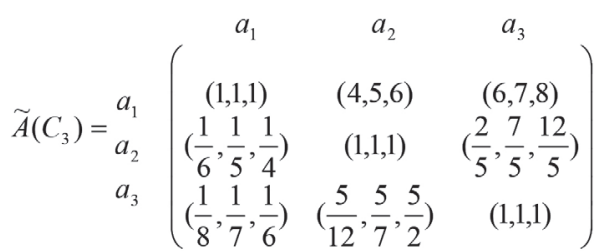

$$
\left.\widetilde{A}\left(C_{4}\right)=\begin{array}{cccc}
a_{1} & a_{2} & a_{3} \\
a_{2} & (1,1,1) & \left(\frac{1}{6}, \frac{1}{5}, \frac{1}{4}\right) & \left(\frac{4}{5}, \frac{9}{5}, \frac{14}{5}\right) \\
a_{3} & (4,5,6) & (1,1,1) & (8,9,9) \\
\left(\frac{5}{14}, \frac{5}{9}, \frac{5}{4}\right) & \left(\frac{1}{9}, \frac{1}{9}, \frac{1}{8}\right) & (1,1,1)
\end{array}\right)
$$

(Reader can compare the matrices to the matrices (3.1).)

Using these matrices and formula (2.6) we obtain fuzzy evaluations of options with respect to each criteria.

Consider $m$ options that we evaluate according to $n$ criteria. The fuzzy weights of the criteria with respect to the overall goal are denoted by $\widetilde{v}_{i}, i=1, \ldots, n$.

The fuzzy evaluation of the option $a_{j}$ with respect to the criterion $C_{i}$ is denoted by $\widetilde{h}_{j}^{i}, j=1, \ldots, m, i=1, \ldots, n$.

The overall fuzzy evaluation of the option $a_{j}$ with respect to the overall goal (taking into account all the criteria) is denoted by $\tilde{h}_{j}$.

Partial fuzzy evaluation of the option $a_{1}$ (shipping) using individual criteria are

$$
\begin{aligned}
& \widetilde{h}_{1}^{1}=(0,1058 ; 0,2286 ; 0,3102), \\
& \widetilde{h}_{1}^{2}=(0,1196 ; 0,1667 ; 0,2199), \\
& \widetilde{h}_{1}^{3}=(0,1664 ; 0,7447 ; 0,8235), \\
& \widetilde{h}^{4}=(0,6446 ; 0,1525 ; 0,2016) .
\end{aligned}
$$

Partial fuzzy evaluation of the option $a_{2}$ (railway) using individual criteria are

$$
\begin{aligned}
& \widetilde{h}_{2}^{1}=(0,5915 ; 0,6857 ; 0,7572), \\
& \widetilde{h}_{2}^{2}=(0,0673 ; 0,0833 ; 0,1219), \\
& \widetilde{h}_{2}^{3}=(0,0847 ; 0,1489 ; 0,2056), \\
& \widetilde{h}_{2}^{4}=(0,6900 ; 0,7627 ; 0,8161) .
\end{aligned}
$$

Partial fuzzy evaluation of the option $a_{3}$ (aviation) using individual criteria are

$$
\begin{aligned}
& \tilde{h}_{3}^{1}=(0,0644 ; 0,0857 ; 0,1225), \\
& \widetilde{h}_{3}^{2}=(0,6768 ; 0,7500 ; 0,8032), \\
& \widetilde{h}_{3}^{3}=(0,0770 ; 0,1064 ; 0,1850), \\
& \widetilde{h}_{3}^{4}=(0,0681 ; 0,0847 ; 0,1275) .
\end{aligned}
$$

We will calculate the total fuzzy scores for option $a_{j}$ according to the definition of fuzzy weighted average (Pavlačka, 2007).

For the calculation of significant values $\tilde{h}_{j}=\left(h_{j 1}, h_{j 2}, h_{j 3}\right)$ of option $a_{j}$ we use formulas (2.7), (2.8) and (2.9).

Thus, the resulting fuzzy evaluation for individual options (including all criteria) are

$$
\begin{aligned}
& \widetilde{h}_{1}=(0,1647 ; 0,2537 ; 0,3658) \text { (shipping), } \\
& \widetilde{h}_{2}=(0,4579 ; 0,6037 ; 0,7078) \text { (railway), } \\
& \widetilde{h}_{3}=(0,0983 ; 0,1426 ; 0,2268) \text { (aviation). }
\end{aligned}
$$

Using the formula (2.10) we obtain the centre of gravity of these fuzzy numbers:

$$
t\left(\widetilde{h}_{1}\right)=0,2614 ; t\left(\widetilde{h}_{2}\right)=0,5898 ; t\left(\widetilde{h}_{3}\right)=0,1559 .
$$

The resulting order of options is then:

1. Railway transport $\left(a_{2}\right), 2$. Shipping transport $\left(a_{1}\right), 3$. Aviation transport $\left(a_{3}\right)$. 


\section{DISCUSSION / Rasprava}

The method offered here is general and can be applied to different systems with different criteria. One can change the criteria and input data to consider different cases. The problems can be solved both by classical and fuzzy formulation depending on the character of the object. In the case of fuzzy formulation one can use the opportunities of the Fuzzy Logic Toolbox MATLAB. As we see under the set of input data and chosen criteria the above proposed method works correctly and railway transport is obtained as more rational one.

\section{CONCLUSION / Zaključak}

In the paper the problem of risk estimate and choice of the rational variants in the transportation using expert information systems are considered. The proposed method for the solution of the considered problem uses the algorithm the pairwise comparison (Saaty's algorithm) to determine the weights of the set criteria. To demonstrate the work of the offered method an example is given that compares logistic risks in shipping, railway and aviation transport. The input data taken in the example are formal and can be chosen for the concrete problems. This example is solved by both non-fuzzy and fuzzy approach. It is shown that with the set of data the railway transport is the optimal option. The results demonstrate the efficiency of the proposed method.

\section{REFERENCES / Literatura}

[1] Andreichikov, A. V., Andreichikova, O. N. (2000). Analysis, Synthesis, Planning Decisions in Economy. Moscow: Nauka.

[2] Azizov, B. B., Karimova, M. L., Mamedov, V. U. (2015). "System approach to decision-making in problems on the basis of the financial analysis of the effectiveness of technologies". Western University Scientific News, Vol. 3, pp. 56-69.

[3] Chawla, S. (2018). "Application of hybrid of Fuzzy Set, Trust and Genetic Algorithm in query log mining for effective Information Retrieval". International Journal of Intelligent Systems and Applications in Engineering, Vol. 6, No. 1, pp. 47-52. https://doi.org/10.18201/ijisae.2018637930
[4] Hamidov, R. H., Mutallimov, M. M., Huseynova, Kh. Y., Javadzada, R. R. (2018). "Reduction of one block linear multicriteria decision-making problem". Advanced Mathematical Models \& Applications, Vol. 3, No. 3, pp. 227-233.

[5] Orlovsky, S. A. (1981). Decision Making Problems with Fuzzy Source Information. Moscow: Nauka.

[6] Pan, Y., Yuan, B. (1997). "Bayesian inference of fuzzy probabilities". International Journal of General System, Vol. 26, No. 1-2, pp. 73-90.

[7] Pashayev, A. F. (2005). "Choice of rational variant of CAS of finding out dangerous loads in air traffics on the basis of expert information". Proceedings of the Fifth International Conference "The microelectronic transformers and devices on their basis", December, 5-6, Baku-Sumgait, pp. 62-65.

[8] Pavlačka, O. (2007). Fuzzy metody rozhodování. Disertační práce, Olomouc: Univerzita Palackého v Olomouci.

[9] Pletnev P. (2014). Risk Management in Logistics. SPbHEU Publishing House.

[10] Rotshtein, A. P., Shtovba, S. D. (2001). "Fuzzy multicriteria analysis of variants with the use of paired comparisons". Journal of Computer and Systems Sciences (International C/C of Tekhnicheskaia Kibernetika), Vol. 40, No. 3, pp. 499-503.

[11] Ruiz, M. C., Romero, E., Pérez, M. A., Fernández, I. (2012). “Development and application of a multi-criteria spatial decision support system for planning sustainable industrial areas in Northern Spain". Automation in Construction, Vol. 22, pp. 320-333. https://doi.org/10.1016/j.autcon.2011.09.009

[12] Saaty, T. L. (1980). The Analytical Hierarchy Process, Planning, Priority. Resource Allocation. RWS Publications, USA

[13] Sałabun, W. (2014). "Application of the fuzzy multi-criteria decision-making method to identify nonlinear decision models". International Journal of Computer Applications, Vol. 89, No. 15, pp. 1-6. https://doi.org/10.5120/15704-4635

[14] Skorospelov, D. (2005). Fuzzy Sets for Exact Conclusions. Company management.

[15] Talašová, J. (2003). Fuzzy metody vícekriteriálního hodnocení a rozhodování, 1. vydání. Olomouc: Univerzita Palackého v Olomouci.

[16] Tzeng, G. H., Huang, J. J. (2011). Multiple Attribute Decision Making: Methods and Applications. Chapman and Hall/CRC.

[17] Uhrmacher, A. M., Weyns, D. (eds.). (2009). Multi-Agent Systems: Simulation and Applications. CRC press.

[18] Velasquez, M., Hester, P. T. (2013). "An analysis of multi-criteria decision making methods". International Journal of Operations Research, Vol. 10, No. 2 pp. 56-66.

[19] Vlkovský, M., Šmerek, M., Michálek, J. (2017). "Cargo securing during transport depending on the type of a road". IOP Conference Series: Materials Science and Engineering, Vol. 245, No. 4, 042001. https://doi.org/10.1088/1757$899 x / 245 / 4 / 042001$

[20] Yeh, C., Ritchie, S. G., Schneider, J. B. (1986). „Potential applications of knowledge-based expert systems in transportation planning and engineering". Transportation Research Record, Vol. 1076, pp. 59-65. 